\title{
Autosomal recessive
}

INSERM

\section{Source}

INSERM. (1999). Orphanet: an online rare disease and orphan drug data base. autosomal recessive. ORPHA:409930

Pattern of inheritance in which two mutated alleles of the same gene located on one of the 22 autosomes (non-sexual chromosomes) are needed to express the phenotype. 